\title{
APPLYING GRAPHIC ORGANIZERS STRATEGYON GRADE TEN STUDENTS VOCABULARY ACQUISITION
}

\author{
Abdilah $^{1}$, Robiatul Adawiyah ${ }^{2}$ \\ Universitas Islam As-Syafi'iyah Jakarta
}

\begin{abstract}
The purpose of this research was investigating of applying graphic organizers strategy on grade ten students' vocabulary acquisition at SMA Martia Bhakti Bekasi, particularly to find out whether or not graphic organizers has significance effect on students' vocabulary acquisition. The population of this research was the students on grade ten at SMA Martia Bhakti Bekasi, with the total number 225 students. Samples were gotten by adoptingcluster random sampling with the total number 60 students who is sitting on 2 classes. One of classes was assigned to an experimental group, whose students were taught using the GO strategy with five specific features of vocabulary items, they are definition, synonym, antonym, example, and using it in an example sentences. While the other class was assigned to be control group, whose students were taught with the same vocabulary items using conventional strategy. The research methodology used quasi experiment method and the research design adopted post test only control group design. After gave the treatment to the experiment and control groups, the post testwas conductedformeasuringeffectivenessof the treatment, numbering 30 items. At the end of the session, the data was analyzed using SPSS v. 21. The researcher used One-Way ANOVA for analysis. The result showed that the $\mathrm{F}$ observed is higher than $\mathrm{F}$ table (4.00, come from significant level 0.05 and $\mathrm{df}=1 / 58)$. It means that graphic organizers strategy has significant effect on students' vocabulary acquisition.
\end{abstract}

Key words: Graphic organizers, vocabulary, vocabulary acquisition. 


\section{Introduction}

Vocabulary acquisition is very important for the students when they want to master the skills in the language. Kridalaksana (1993, p. 127) stated that vocabulary is a component of a language maintaining all of information about meaning and using word in a language. It means that vocabulary is cover all the skills (listening, speaking, reading and writing) in the language because vocabulary is basic for learners before they mastery the skills, they must know about the meaning of word and after that, they can use the word in a language well.

In the KTSP curriculum, the purpose of learning English that must be achieved is students are able to communicate includes listening, speaking, reading and writing as the ideal condition. However, the real condition has not yet been satisfactorily achieved, as evidenced from National Examination. The writer got the result of National Examination of senior high school in 2015 and 2016, the average competency achievement percentage in 2015 is $61.29 \%$,Andthe average competency achievement percentage in 2016 is $54.78 \%$, it is including English subject. Based on the data, the writer found out several factors has influenced the score of National Examination, one of the factors is the students have low vocabulary. If the students have low vocabulary, they cannot get the meaning from what they have read, and they cannot answer the question in the UN, because almost subject in $\mathrm{UN}$ is consist of reading.

The teachers must have a good learning strategy to improve their students' vocabulary acquisition. One of the strategies that be reputed to be effective in the 
teaching vocabulary is Graphic organizers. According to Tsubaki (2012, p. 58) graphic organizers are a promising device for meaningful learning, and they can also be the basis of an effective learning strategy. Strangman, Vue, Hall \& Meyer (2014, p. 2) also argued that:

"A graphic organizer is a visual and graphic display that depicts the relationships between facts, term, and /or ideas within a learning task. Graphic organizers are also sometimes referred to as knowledge maps, concept maps, story maps, cognitive organizers, advance organizers or concept diagram".

So, graphic organizer is strategy to make learning vocabulary more meaningful. Graphic Organizers (GO) make students easier to learn not only the meaning of word, but also it can be help students to learn about the specific items of vocabulary, such as synonym, antonym, and use words in a example sentences.

\section{Previousrelevant Researches}

Several researchers have investigated about graphic organizer on vocabulary acquisition. First, Arwa N. Al-Hinnawi (2012), the result showed that using GO strategy was more effective in improving students' vocabulary building than the conventional instruction. Second, Zardak, Ali, Omidvari (2015), the revealed result showed that the experimental group students performed better than the control group students, concerning their vocabulary development and also revealed that this strategy improved the students' vocabulary development. Third, Shoari and Farrokhi (2014), This study aimed at investigating the effect of graphic organizer strategy onimproving Iranian EFL learners' vocabulary learning. The 
result showed that the null hypothesis is rejected here and it is proved that graphic organizer strategy improved the vocabulary learning.

Based on the theorists above, the writer conducted research in the same area. This research was conducted in SMA Martia Bhakti Bekasi. The aim of the research is to find out whether or not, using Graphic Organizers can improve students' vocabulary acquisition.

\section{Method}

\section{Research Design and research method}

The research method that was used is Quasi-Experimental Method. It means that treatment condition did not allow a strict control. In this research, vocabulary items were taught to the experimental group students using the GO strategy, while the students in the control group were taught by using conventional strategy. The design of this research was post-test only control group design.

\section{Participants}

This research involved all the students on grade ten at SMA Martia Bhakti Bekasi in the academic year 2016/2017 with the total number 225 students as the population. The subjects were 60students who joined two intact classes which were randomly assigned to an experimental group and a control group with 30 students in each.

\section{Material}

The material taught to students in both experimental and control groups included all the vocabulary items from the text in the lesson plan. Students of both groups 
were required to study vocabulary items with five specified items, definition, synonym, antonym, example, and use the word in the example sentence.

\section{Hypotheses}

1. Null hypothesis

There is no significant effect of using Graphic Organizers on students' vocabulary acquisition at SMA Martia Bhakti Bekasi.

2. Alternative hypothesis

There is significant effect of using Graphic Organizers on students' vocabulary acquisition at SMA Martia Bhakti Bekasi.

\section{Indicators of Vocabulary Acquisition}

The writer took score from indicators of vocabulary acquisition, as follows:

1. Students are able to recognize synonym,

2. Students are able to recognize antonym,

3. Students are able to define the meaning of word,

4. Students are able to determine the meaning of word based on the context, and

5. Students are able to use the word in the right context.

\section{Instrument}

Before starting the treatment to the experiment and control groups, the writer tried out 60 questions to the try-out class. Then, the result analyzed the validity, reliability, difficulty index, and discrimination of power. After that, 37 
good questions items have gotten, but for simplification, the questions item that was used only 30 questions items.

\section{Procedures of the study}

1. Planning: This research including formulating the research questions, reviewing the literature related to the variables under study, formulating hypothesis, constructing the blueprints, and specifying the indicators, developing question items, for each indicator, conducting a tryout, analyzing the question items in terms of validity, reliability, discrimination power, and difficulty index, determining the research method and design, and constructing the lesson plans.

2. Collecting Data: After the treatment, the writer distributed the post test to the experiment and control class in different times then researcher collected the data.

3. Analyzing the Data: Inferential statistic of ANOVA is preceded by the test of normality and homogeneity and analyzed the post test using SPSS v.21.

4. Reporting: In this step, after applied the strategy, distributed the posttest, collected the data and analyzed the data, the researcher reporting the data in the form writing of the research by using the formal frame of writing.

\section{Result}

To answer the question of this research, relating to whether the GO strategy had an effect on students' vocabulary acquisition at SMA Martia Bhakti 
Bekasi, the data were analyzed descriptively and inferentially. The descriptive table as follows:

Table 1 : Descriptive Statistics

\begin{tabular}{|c|c|c|c|}
\hline \multicolumn{2}{|l|}{ Statistics } & Experiment Class & Control Class \\
\hline \multirow[t]{2}{*}{$\mathrm{N}$} & Valid & 30 & 30 \\
\hline & Missing & 0 & 0 \\
\hline Mean & & 73.11 & 65.00 \\
\hline Std. Error of Mean & & .798 & .654 \\
\hline Median & & 71.67 & 66.67 \\
\hline Mode & & 70 & 67 \\
\hline Std. Deviation & & 4.371 & 3.583 \\
\hline Variance & & 19.106 & 12.835 \\
\hline Skewness & & .327 & -1.339 \\
\hline Std. Error of Skewness & & .427 & .427 \\
\hline Kurtosis & & -1.185 & 1.077 \\
\hline Std. Error of Kurtosis & & .833 & .833 \\
\hline Range & & 13 & 13 \\
\hline Minimum & & 67 & 57 \\
\hline Maximum & & 80 & 70 \\
\hline Sum & & 2193 & 1950 \\
\hline
\end{tabular}

From the table above, can be seen that the value of the Mean or the arithmetic Mean for grade experiment and control 73, 11 and 65, 00. While the maximum score in the experiment group is 80 , in the control group is 70 . Then, the data analyzed used One-Way ANOVA in SPSS v.21 after did pre-requisite to data analysis, normality test and homogeneity test. The result of data analysis is presented as follows:

\section{ANOVA}

Score

\begin{tabular}{|l|c|c|c|c|c|}
\hline & $\begin{array}{c}\text { Sum of } \\
\text { Squares }\end{array}$ & df & $\begin{array}{c}\text { Mean } \\
\text { Square }\end{array}$ & F & Sig. \\
\hline $\begin{array}{l}\text { Between } \\
\text { Groups }\end{array}$ & 1251.267 & 1 & 1251.267 & 50.410 & .000 \\
\hline
\end{tabular}




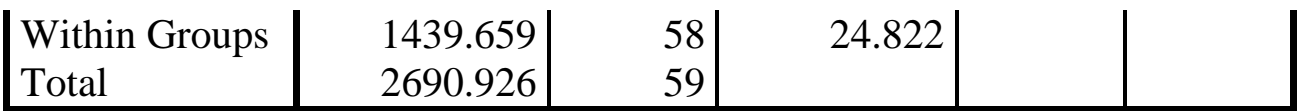

The calculation showed that significance value is 0.000 . The significance value 0.000 is lower than $(<) 0.05$, so $\mathrm{H}_{0}$ (sig. value $>0.05$ ) was rejected and $\mathrm{H}_{\mathrm{A}}$ (sig. value $<0.05$ ) was accepted. $\mathrm{F}_{\text {observed }}$ also can be used to find out whether or not there is an effect of variable $\mathrm{X}$ on $\mathrm{Y}$ through comparing with $\mathrm{F}$ table. $\mathrm{F}$ table is got from the determine $\mathrm{df}_{1}$ and $\mathrm{df}_{2}$, $\mathrm{df}_{1}=\mathrm{K}-1(2-1=1)$ and $\mathrm{df}_{2}=$ samples $-\mathrm{k}(60-2=58)$, the result are $\mathrm{df}_{1}=1, \mathrm{df}_{2}$ $=58$, and $\mathrm{F}$ table was obtained $=4.01$. The researcher found that there is effect of variable $\mathrm{X}$ on variable $\mathrm{Y}$ because $\mathrm{F}$ observed $(50.410)>\mathrm{F}$ table (4.01). It can be concluded that there is significant effect of variable $X$ (graphic organizers) on variable Y (vocabulary acquisition).

\section{Discussion}

This research was conducted at SMA Martia Bhakti Bekasi in Academic year of 2016/2017, it concerned with the study of the effect of graphic organizers on Students' vocabulary acquisition. It also intends to prove the theories which were advanced by Nicole, Vue, \& Hall (2004), Zardak et al, (2015), on the effectiveness of graphic organizers on students' vocabulary acquisition.

In addition, this research proved there was significant effect of graphic organizers on students' vocabulary acquisition and empirically this research proved the above mentioned theories and beside that verified the 
previous relevant researches conducted by Zardak, Kazemi \& Omidvarid (2015),Al-Hinnawi (2012), Farrokhi and Shoari (2014).

The findings of this study showed that after $X_{.2}$ as the experimental class got the treatment using graphic organizers, it revealed that students tend to be more fun, more active, interest and enjoy learning English. It can be seen from the result of statistical analysis using OneWay ANOVA, the calculation showed that significance value is 0.000 and $\mathrm{F}$ observed 50.410. It means that significance (sig.) value lower than $(<) 0.05$ and $\mathrm{F}$ observed higher than $(>) \mathrm{F}$ table 4.01. So $\mathrm{H}_{0}$ was rejected and $\mathrm{H}_{\mathrm{A}}$ was accepted. Most of the students who were taught using graphic organizers obtained higher scores than students in control class who were taught using conventional method.

In experimental class there were some students who got lower scores than those in the control class. But on the other hand, in control class (X.3), which did not get the treatment like experimental class, even though mostly got lower scores, there were some students in control class who obtained higher scored but based on the result, the students in experimental class performed better than those who were in control class. This better performance was largely caused by the treatment they received in the experimental class adopting graphic organizers.

Based on the statistical calculation, the writer concluded that there was effect of graphic organizers on students' vocabulary acquisition at SMA Martia Bhakti Bekasi in the academic year of 2016/2017. 


\section{Conclusion}

Based on the result of data analysis of this research, such as normality test, homogeneity test, and ANOVA, it can be concluded that there is an effect of applying graphic organizers strategy on grade ten students' vocabulary acquisition at SMA Martia Bhakti Bekasi in the academic year 2016/2017.

In addition, graphic organizers make the learning activity more enjoyable and interesting because the students learn vocabulary by using the types of graphic organizers that they created by themselves in the paper and they can define the word based on their own opinion. The suggestion for English teachers is must know the steps of using graphic organizers well in order to be applied effectively in their classroom.It is also suggested for school that this strategy helpful in teaching and learning process and help students to acquire vocabulary easier. 


\section{References}

Antara News. (2015, Mei 15). Kemendikbud: Rata rata Nilai Ujian Nasional Naik 0,3 Poin. Retrieved September 27, 2016, from Antara News Web site: http://m.antaranews.com

Antara News. (2016, Mei 09). Ujian Nasional SMA 2016 Meningkat. Retrieved September 3, 2016, from Antara News Web site: http://antaranews.com

Arwa, N. A. (2012, September 17). The Effect of The Graphic Organizers Strategy on University Students' English Vocabulary Building, Vol. 5 (12). Retrieved August 05, 2016, from Canadian Center of Science and Education: http://dx.doi.org/10.5539/elt.v5n12p62

Dardjowidjodjo, S. (2005). Psikolinguistik: Pengantar Pemahaman Bahasa Manusia (ed.2). Jakarta: Yayasan Obor Indonesia.

Departemen Pendidikan dan Kebudayaan. (1999). Garis-garis Besar Program Pengajaran Kurikulum 1994 SLTP/SLTA Mata Pelajaran Bahasa Inggris. Jakarta: Depdikbud.

Depdiknas, Kurikulum 2004. Standar Kompetensi Mata Pelajaran Bahasa Inggris SMA/MA. Jakarta: Depdiknas, 2004.

Depdiknas, Kurikulum 2006. Standar Kompetensi Mata Pelajaran Bahasa Inggris SMA/MA. Jakarta: Depdiknas, 2006.

Farrokhi, F., \& Shoari, E. (2014). The Effect of Graphic Organizers Strategy on Improving Iranian EFL Learners' Vocabulary Acquisition, Vol. 1 (3). IJRELT , 71-82.

FKIP PS-PBI UIA. (2016). Panduan Skripsi 2016. Jakarta: FKIP PS-PBI UIA

Kemendikbud. (2016, Mei 09). Indeks Integritas Ujian Nasional SMA 2016 Meningkat. Retrieved October 05, 2016, from Kemendikbud Web site: http://www.kemendikbud.go.id

Kridalaksana, H. (1993). Kamus Lingusitic, (ed.3). Jakarta: PT. Gramedia Pustaka Utama.

Metrotv News. (2016, Mei 09). Ujian Nasional SMA 2016. Retrieved September 19, 2016, from Metrotv News Web site: http://metrotvnews.com 
Nicole, S., Ge, V., Hall, \& Meyer. (2004). Graphic Organizers and Implications for Universal Design for Learning, Curriculum Enhancement Report. National Center on Accessing The General Curriculum (NCAC).

Tsubaki, M. (2012). Vocabulary Learning with Graphic Organizers In The EFL Environment: Inquiry Into The Involvement Load Hypothesis. United States: Proquest.

Zardak, Kazemi, \& Omidvarid. (2015). The Effect of The Graphic Organizers Strategy on The Development of Intermediate EFL Learners' Vocabulary, Vol. 5 (S3). Indian Journal of Fundamental and Applied Life Sciences, 1033-1047. 